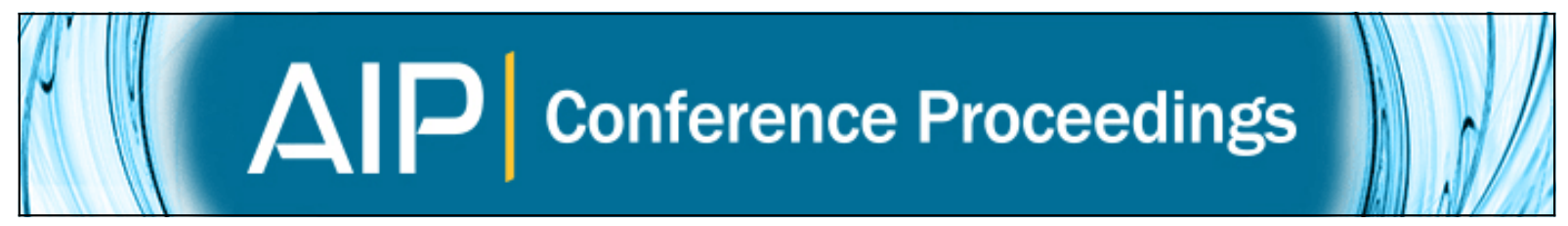

\title{
Exploring the TQM best practices in Malaysia hotel industry using Multi-Criteria Decision Making (MCDM) approach: A conceptual analysis
}

Sin Kit Yeng, Muhammad Shahar Jusoh, Noormaizatul Akmar Ishak, and Muhammad Zaini Ahmad

Citation: AIP Conference Proceedings 1775, 030093 (2016); doi: 10.1063/1.4965213

View online: http://dx.doi.org/10.1063/1.4965213

View Table of Contents: http://scitation.aip.org/content/aip/proceeding/aipcp/1775?ver=pdfcov

Published by the AIP Publishing

\section{Articles you may be interested in}

Multi-objective optimization of a natural aspirated three-cylinder spark ignition engine using modified nondominated sorting genetic algorithm and multicriteria decision making

J. Renewable Sustainable Energy 8, 025705 (2016); 10.1063/1.4945573

Solving complex maintenance planning optimization problems using stochastic simulation and multi-criteria fuzzy decision making

AIP Conf. Proc. 1637, 766 (2014); 10.1063/1.4904649

FSAW for REIT selection in multi-criteria decision making

AIP Conf. Proc. 1605, 1098 (2014); 10.1063/1.4887744

Operator performance evaluation using multi criteria decision making methods

AIP Conf. Proc. 1602, 559 (2014); 10.1063/1.4882540

SU-FF-T-50: A Systematic Approach to Practical Multi-Criteria IMRT Planning

Med. Phys. 34, 2412 (2007); 10.1118/1.2760698 


\title{
Exploring the TQM Best Practices in Malaysia Hotel Industry Using Multi-Criteria Decision Making (MCDM) Approach: A Conceptual Analysis
}

\author{
Sin Kit Yeng ${ }^{1, a)}$, Muhammad Shahar Jusoh ${ }^{1, b)}$, Noormaizatul Akmar Ishak ${ }^{2, c)}$ and \\ Muhammad Zaini Ahmad,d) \\ ${ }^{1}$ School of Business Innovation \& Technopreneurship, \\ Universiti Malaysia Perlis (UniMAP), 01000 Kangar, Malaysia. \\ ${ }^{2}$ School of Human Development and Technocommunication, \\ Universiti Malaysia Perlis (UniMAP), 02600 Jejawi, Perlis Malaysia. \\ ${ }^{3}$ Institute of Engineering Mathematics, \\ Universiti Malaysia Perlis (UniMAP), Kampus Pauh Putra, \\ 02600, Arau, Perlis, Malaysia. \\ ${ }^{a}$ Corresponding author: sinkityeng8190@gmail.com \\ b)shahar@unimap.edu.my \\ c)maizatul@unimap.edu.my \\ d)mzaini@unimap.edu.my
}

\begin{abstract}
Quality has become a fundamental issue for organizational success in today's dynamic business environment particularly hotel industry as it affects the stakeholders which involve government, employers, employees as well as the end users. Total Quality Management (TQM) has seen as a revolution in management whereby it not only began to exert its vigorous effect on national business system but also referred as an comprehensive approach for total organizational performance improvement. TQM literature has been widely addressed and many researchers evaluated the gaps in TQM to achieve organizational performance. However, the literature does not seem to agree on a universal framework for the implementation of TQM philosophy in hotel settings. This paper emphasizes the importance level of inter-dependency among the TQM which has rarely been explored in the preceding studies. A novel hybrid Multi-Criteria Decision Making (MCDM) model is used to address the dependence relationships of factors with the aid of grey relational analysis, Analytical Network Process (ANP) and Decision-Making Trial and Evaluation Laboratory (DEMATEL). The initial model of the study is designed by considering main criteria and sub-criteria of TQM using interview method. DEMATEL is employed to construct interrelations among criteria and sub-criteria in the integrated model. By using this approach, the inter-dependencies strength among the criteria and sub-criteria is tested. The ANP method is then applied in order to determine the relative importance of the TQM and used to identify how TQM are weighted and prioritized by the management representatives (MR) or hotel top management. The development of this MCDM model will assist Malaysia hotels in identifying the key elements and factors that need to be thoroughly considered and managed for achieving competitive advantage as well as be a guide for hotel entities to invent new quality management practices or improve existing management policies.
\end{abstract}

\section{INTRODUCTION}

In this era of global competitive environment, with excessive substitution products, services and destinations are being offered, the understanding of quality term is transformed not only as an issue that is necessary to be solved but quality is seen especially as a competitive opportunity in tourism industry [1]. Being as an active destination for business and meetings, incentives, conferences, and exhibitions (MICE), Malaysia has to enhance the quality of 